\title{
A study on carbon emission calculation of residential buildings based on whole life cycle evaluation
}

\author{
Mei Shang ${ }^{1 *}$, Haochen Geng ${ }^{1}$ \\ ${ }^{1}$ School of Management, Xi'an University of Science and Technology, Xi'an, Shaanxi, China
}

\begin{abstract}
The whole life cycle carbon emission of buildings was calculated in this paper. Based on the whole life cycle evaluation theory, a carbon emission calculation model was established by using a single urban building as an example. The whole life cycle building of carbon emission calculation includes five stages: planning and design, building materials preparation, construction, operational maintenance, as well as dismantlement. It provides a reference for standardizing the calculation process of building carbon emissions by analyzed the carbon emissions and composition characteristics of each stage of the life cycle of the case house. The calculation results demonstrate that the carbon emission during the operational maintenance and building materials preparation stages in the whole life cycle of the building account for $78.05 \%$ and $20.59 \%$ respectively. These are the two stages with the greatest emission reduction potential.
\end{abstract}

\section{Introduction}

In China, carbon emissions from buildings account for up to $36 \%$ of total carbon emission ${ }^{[1]}$. Reducing carbon emissions of products represented by buildings has become an urgent task. In this view, buildings are bound to develop in the direction of low energy consumption, which involves the calculation and reduction of carbon emissions throughout the building life cycle.

Life cycle assessment is considered in the field of environmental studies as the only reasonable criterion for the selection of materials, components and equipment, and as the main method for conducting environmental impact assessment $^{[2]}$. Life cycle assessment is now widely used in current environmental policy development and in the calculation of carbon emissions from buildings. Jaehun Sim et al. used a life cycle evaluation method to analyze seven air pollutants in a Korean apartment building, and the results showed that the main contributing building materials were concrete as well as steel ${ }^{[3]}$. Leif Gustavsson et al. calculated the $\mathrm{CO}_{2}$ emissions of buildings from a whole life cycle perspective through the emission factor method $^{[4]}$. China started late in calculating carbon emissions over the whole life cycle of buildings, and Liu et al. calculated carbon emissions over the whole life cycle of buildings in four stages, and the results showed that buildings reached the highest carbon emissions in the use and maintenance stages ${ }^{[5]}$. Zhang et al. studied the environmental impact data of different residential areas in Beijing in depth and quantified the analysis, and the results showed that the environmental impact per unit building area was much greater in high-rise buildings ${ }^{[6]}$.

However, the currently research results lack unified standards in the construction of building carbon emission calculation models, such as the selection of carbon emission factors, the assumption of calculation conditions, and the definition of calculation boundaries are inconsistent. The division of building life cycle stages is also considered incompletely. Therefore, this paper comprehensively considers each stage of the building life cycle based on the life cycle evaluation method and establishes a calculation model, which is combined with a case study to analyze the carbon emission composition of each stage of the building in order to provide a sample case reference for the improvement of the building carbon emission calculation research.

\section{Building life cycle calculation model}

This paper establishes a carbon emission calculation model based on the whole life cycle evaluation combined with the carbon emission coefficient method to calculate carbon emissions for each stage of the whole life cycle of a building.

\subsection{Calculation Boundary}

The calculation boundary of building carbon emissions starts from the entire life cycle of the building, and should be calculated at any stage involving greenhouse gas emissions, including process, input or output. In this paper, the calculation boundary of carbon emissions for buildings includes office equipment carbon emissions in the planning and design phase, production and transportation carbon emissions in the preparation phase of building materials, mechanical carbon emissions in the construction and construction phase, carbon emissions in temporary facilities, and carbon emissions in the operation and maintenance phase, carbon emissions 
during the dismantlement process.

\subsection{Calculation unit}

In this paper, the functional unit is "kgCO2e/(m2-a)", which is the $\mathrm{CO}_{2}$ equivalent per square meter of building area per year. This unit of calculation can effectively eliminate the influence of different sizes and design years of buildings, and make the accounting results consistent and comparable with each other.

\subsection{Carbon emission factor analysis}

The emission factor method, also known as the emission factor method or IPCC inventory method, is a widely used method for calculating carbon emissions today. The determination of carbon emission factors is a prerequisite for performing carbon emission calculations for buildings. In the building sector, carbon emission factors are determined in the following ways.

\subsubsection{Fossil fuel and electricity carbon emission factors}

In this paper, the carbon emission factor of fossil fuels is obtained by selecting the $\mathrm{CO} 2$ emission factor per unit calorific value (tCO2/TJ) of major fossil fuels from Appendix A of GB/T51366-2019 Carbon Emission Calculation Standard for Buildings, and then finding the average of each fuel from the Reference Coefficient for Converting Standard Coal of Various Energy Sources in Appendix A of GB/T2589-2008 of China's General Rules for Comprehensive Energy Consumption Calculation. The low calorific value is obtained by multiplying the two; the carbon emission factor of electric power adopts the average carbon emission factor of regional power grid published by National Development and Reform Commission, and the results are collated in Table 1.

Table 1 Fossil fuel carbon emission factors

\begin{tabular}{ccc}
\hline Fuel type & Unit & $\begin{array}{c}\text { Carbon emission } \\
\text { factor } \\
\text { (kgCO2e/unit) }\end{array}$ \\
\hline Bituminous & $\mathrm{kg}$ & 1.861 \\
Coal & $\mathrm{kg}$ & 2.861 \\
Coke & $\mathrm{kg}$ & 3.020 \\
Crude Oil & $\mathrm{kg}$ & 2.925 \\
Gasoline & $\mathrm{kg}$ & 3.096 \\
Diesel & $\mathrm{m}^{3}$ & 2.068 \\
Natural Gas & $\mathrm{kWh}$ & 0.6671 \\
Electricity &
\end{tabular}

\subsubsection{Carbon emission factors for major building materials and transportation modes}

The selection of carbon emission factors of construction materials in this study is based on the original data sources of the case building (such as the bill of quantities), and the carbon emission factors of the building materials inventory in the Standard for Calculation of Carbon Emission of Buildings, and then the required carbon emission factors of building materials are selected from the relevant studies of domestic and foreign scholars. The transportation mode carbon emission factors of the building materials transportation stage adopt the research results of Luo Zhixing ${ }^{[7]}$. The main transportation mode carbon emission factors are shown in Table 2.

Table 2 Carbon emission factors of transportation modes

\begin{tabular}{ccc}
\hline $\begin{array}{c}\text { Transportation } \\
\text { method }\end{array}$ & Unit & $\begin{array}{c}\text { Carbon } \\
\text { emission } \\
\text { factor }\end{array}$ \\
\hline Rail transportation & $\begin{array}{c}\mathrm{kgCO} 2 \mathrm{e} / \\
\left(10^{2} \mathrm{t} . \mathrm{km}\right)\end{array}$ & 0.923 \\
$\begin{array}{c}\mathrm{kgCO} 2 \mathrm{e} / \\
\text { Road transportation } \\
\text { (gasoline) }\end{array}$ & $\begin{array}{c}\left(10^{2} \mathrm{t} . \mathrm{km}\right) \\
\mathrm{kgCO} 2 \mathrm{e} /\end{array}$ & 22.8 \\
$\begin{array}{c}\left(10^{2} \mathrm{t} \cdot \mathrm{km}\right) \\
\text { Road transportation } \\
\text { (diesel) }\end{array}$ & 19.6 \\
\hline
\end{tabular}

\subsubsection{Carbon emission factor of construction machinery}

In this paper, the unit shift energy consumption of construction machinery in "Construction Carbon Emission Calculation Standard" is the main focus. The relevant research results of scholars are collected, and some of the machinery is organized as follows in Table 3.

Table 3 Carbon emission factors of some construction machinery

\begin{tabular}{ccc}
\hline $\begin{array}{c}\text { Machinery category } \\
\text { and specifications }\end{array}$ & $\begin{array}{c}\text { Unit shift energy } \\
\text { consumption }\end{array}$ & $\begin{array}{c}\text { Carbon } \\
\text { emission } \\
\text { factor } \\
\text { (kgCO2e/unit) }\end{array}$ \\
\hline Dump truck $20 \mathrm{~m}^{3}$ & $52.93 \mathrm{~kg}$ (diesel) & 163.87 \\
Loader $1.5 \mathrm{~m} 3$ & $58.75 \mathrm{~kg}($ diesel $)$ & 181.89 \\
$\quad$ Road roller & $42.95 \mathrm{~kg}($ diesel $)$ & 132.97 \\
$\quad$ CLG6122e & $30.21 \mathrm{~kg}$ (gasoline) & 88.36 \\
Water sprinkler & & \\
$\quad$ 4000L & $29.52 \mathrm{~kg}($ diesel $)$ & 91.39 \\
Crawler crane $15 \mathrm{t}$ & $45.66 \mathrm{kWh}$ & 30.46 \\
Lifting machine & & \\
100m & &
\end{tabular}

\subsection{Building life-cycle carbon emission calculation formula}

\subsubsection{Formula for calculating carbon emissions in the planning and design phase}

$$
\mathrm{C}_{\mathrm{GH}}=\sum_{\mathrm{i}=1}^{\mathrm{n}} \mathrm{E}_{\mathrm{gh}, \mathrm{i}} \mathrm{F}_{\mathrm{i}}
$$

$\mathrm{C}_{\mathrm{GH}}$ is the total carbon emission in the planning and design phase $(\mathrm{kgCO} 2 \mathrm{e})$; $\mathrm{E}_{\mathrm{gh}, \mathrm{i}}$ is the total usage of the ith energy source in the planning and design phase $(\mathrm{kWh}$ or $\mathrm{kg}) ; \mathrm{F}_{\mathrm{i}}$ is the carbon emission factor of the ith energy source $(\mathrm{kgCO} 2 \mathrm{e} / \mathrm{kWh}$ or $\mathrm{kgCO} 2 \mathrm{e} / \mathrm{kg})$

\subsubsection{Carbon emission calculation formula for building materials preparation stage}

The preparation stage of building materials specifically includes the production stage of building materials and the transportation stage of building materials. The carbon 
emissions of the two stages are calculated separately and summarized to get the total carbon emissions of the preparation stage of building materials. Carbon emission calculation of the building materials preparation stage.

$$
\mathrm{C}_{\mathrm{ZB}}=\mathrm{C}_{\mathrm{sc}}+\mathrm{C}_{\mathrm{ys}}
$$

$\mathrm{C}_{\mathrm{ZB}}$ is the total carbon emission in the preparation stage of building materials $(\mathrm{kgCO} 2 \mathrm{e}) ; \mathrm{C}_{\mathrm{sc}}$ is the carbon emission in the production stage of building materials $(\mathrm{kgCO} 2 \mathrm{e}) ; \mathrm{C}_{\mathrm{ys}}$ is the carbon emission in the transportation stage of building materials $(\mathrm{kgCO} 2 \mathrm{e})$.

$$
\mathrm{C}_{\mathrm{SC}}=\sum_{\mathrm{i}=1}^{\mathrm{n}} \mathrm{M}_{\mathrm{i}} \mathrm{F}_{\mathrm{i}}
$$

$\mathrm{C}_{\mathrm{SC}}$ is the carbon emission of the production stage of building materials $(\mathrm{kgCO} 2 \mathrm{e}) ; \mathrm{M}_{\mathrm{i}}$ is the consumption of the ith main building material; $F_{i}$ is the carbon emission factor of the ith main building material (kg CO2e/unit quantity of building materials).

$$
\mathrm{C}_{\mathrm{YS}}=\sum_{\mathrm{i}=1}^{\mathrm{n}} \mathrm{M}_{\mathrm{i}} \mathrm{D}_{\mathrm{i}} \mathrm{T}_{\mathrm{i}}
$$

$\mathrm{C}_{Y S}$ is the carbon emission of the transportation process of building materials $(\mathrm{kgCO} 2 \mathrm{e})$; $\mathrm{Mi}$ is the consumption of the ith main building material $(t) ; D_{i}$ is the average transportation distance of the ith building material $(\mathrm{km}) ; \mathrm{T}_{\mathrm{i}}$ is the carbon emission factor per unit weight of transportation distance under the transportation mode of the $\mathrm{i}^{\text {th }}$ building material $(\mathrm{kgCO} 2 \mathrm{e} / \mathrm{t}-\mathrm{km})$.

\subsubsection{Carbon emission calculation formula for construction phase}

The sources of carbon emissions in the construction phase are mainly: 1) the use of construction machinery; 2) the carbon emissions of temporary facilities, mainly including the energy consumption of the construction site office and the energy consumption of cooking, heating, cooling and lighting in the living area; the carbon emissions of the construction phase can be obtained by summing up the carbon emissions of the above two phases after calculating them respectively.

$$
\mathrm{C}_{\mathrm{JZ}}=\mathrm{C}_{\mathrm{sg}}+\mathrm{C}_{\mathrm{ls}}
$$

$\mathrm{C}_{\mathrm{JZ}}$ is the total carbon emission during construction stage $(\mathrm{kgCO} 2 \mathrm{e}) ; \mathrm{C}_{\mathrm{sg}}$ is the carbon emission of construction machinery during construction $(\mathrm{kgCO} 2 \mathrm{e})$; $\mathrm{C}_{\mathrm{ls}}$ is the carbon emission during operation of temporary facilities $(\mathrm{kgCO} 2 \mathrm{e})$.

$$
\mathrm{C}_{\mathrm{sg}}=\sum_{\mathrm{i}=1}^{\mathrm{n}} \mathrm{C}_{\mathrm{B}, \mathrm{i}} \mathrm{n}_{\mathrm{i}}
$$

$\mathrm{C}_{\mathrm{sg}}$ is the carbon emission of construction machinery during construction $(\mathrm{kgCO} 2 \mathrm{e}) ; \mathrm{C}_{\mathrm{B}, \mathrm{i}}$ is the carbon emission factor of the $i^{\text {th }}$ type of construction machinery ( $\mathrm{kgCO} 2 \mathrm{e} / \mathrm{shift})$, which can be obtained by multiplying the energy use of each shift of machinery by the corresponding energy carbon emission factor.

$$
\mathrm{C}_{\mathrm{ls}}=\sum_{\mathrm{i}}^{\mathrm{n}} \mathrm{E}_{\mathrm{ls}, \mathrm{i}} \mathrm{F}_{\mathrm{i}}
$$

$\mathrm{C}_{\mathrm{ls}}$ is the total amount of carbon emission during the operation of the temporary facility $(\mathrm{kgCO} 2 \mathrm{e})$; $\mathrm{E}_{\mathrm{ls}, \mathrm{i}}$ is the total amount of the $i^{\text {th }}$ energy consumption during the operation of the temporary facility ( $\mathrm{kWh}$ or $\mathrm{kg}) ; \mathrm{F}_{\mathrm{i}}$ is the carbon emission factor of the $i^{\text {th }}$ energy source $(\mathrm{kgCO} 2 \mathrm{e} / \mathrm{kWh}$ or $\mathrm{kgCO} 2 \mathrm{e} / \mathrm{kg})$.

\subsubsection{Carbon emission calculation formula for operation and maintenance phase}

Carbon emissions from the building operation and maintenance phase include emissions from both building operation and building maintenance processes and are calculated using the formula:

$$
\mathrm{C}_{\mathrm{Y}}=\mathrm{C}_{\mathrm{yx}}+\mathrm{C}_{\mathrm{wh}}
$$

$\mathrm{C}_{\mathrm{Y}}$ is the total carbon emission in operation and maintenance phase $(\mathrm{kgCO} 2 \mathrm{e}) ; \mathrm{C}_{\mathrm{yx}}$ is the carbon emission in building operation process $(\mathrm{kgCO} 2 \mathrm{e}) ; \mathrm{C}_{\mathrm{wh}}$ is the carbon emission in building maintenance process $(\mathrm{kgCO} 2 \mathrm{e})$.

$$
\mathrm{C}_{\mathrm{yx}}=\left(\mathrm{C}_{\mathrm{h}}+\mathrm{C}_{\mathrm{c}}+\mathrm{C}_{\mathrm{l}}+\mathrm{C}_{\mathrm{re}}\right) \times \mathrm{N}
$$

$\mathrm{C}_{\mathrm{yx}}$ is the total carbon emission in operation phase $(\mathrm{kgCO} 2 \mathrm{e}) ; \mathrm{C}_{\mathrm{h}}$ is the annual carbon emission of heating system $(\mathrm{kgCO} 2 / \mathrm{y}) ; \mathrm{C}_{\mathrm{c}}$ is the annual carbon emission of air conditioning system $(\mathrm{kgCO} 2 / \mathrm{y}) ; \mathrm{C}_{1}$ is the annual carbon emission of lighting system $(\mathrm{kgCO} 2 / \mathrm{y}) ; \mathrm{C}_{\mathrm{re}}$ is the annual carbon emission reduction of renewable energy system $(\mathrm{kgCO} 2 / \mathrm{y}) ; \mathrm{N}$ - the service life of the building (y).

$$
\mathrm{C}_{\mathrm{wh}}=\sum_{\mathrm{i}=1}^{\mathrm{n}}(\mathrm{Cwsi}+\mathrm{Cwyi}) \times \mathrm{mi} \times\left[\frac{\mathrm{n}}{\mathrm{ri}}\right]
$$

$\mathrm{C}_{\mathrm{wh}}$ is the carbon emission equivalent of building maintenance and renewal $(\mathrm{kgCO} 2 \mathrm{e}) ; \mathrm{C}_{\mathrm{wsi}}$ is the carbon emission factor of the production and installation of the ith type of building materials and equipment ( $\mathrm{kgCO} 2 \mathrm{e} / \mathrm{unit}) ; \mathrm{C}_{\mathrm{wyi}}$ is the carbon emission factor of the transportation of the ith type of building materials and equipment $(\mathrm{kgCO} 2 \mathrm{e} / \mathrm{unit}) ; \mathrm{m}_{\mathrm{i}}$ is the weight of the $\mathrm{i}^{\text {th }}$ type of building materials or equipment; $n$ is the lifetime of building use; ri is the lifetime of the $i^{\text {th }}$ type of building materials or equipment; $\frac{n}{r i}$ is the number of material or equipment replacement, which should be an integer.

\subsubsection{Carbon emission calculation formula for dismantling treatment phase}

The carbon emissions in the demolition and disposal stage mainly include the carbon emissions caused by energy consumption in the use of demolition machinery and the carbon emissions generated by waste transportation and waste recycling.

$$
\mathrm{C}_{\mathrm{C}}=\mathrm{C}_{\mathrm{cc}}+\mathrm{C}_{\mathrm{fys}}+\mathrm{C}_{\mathrm{hs}}
$$

$\mathrm{C}_{\mathrm{C}}$ is the total carbon emission in the dismantling and treatment stage $(\mathrm{kgCO} 2 \mathrm{e}) ; \mathrm{C}_{\mathrm{cc}}$ is the carbon emission in the dismantling stage $(\mathrm{kgCO} 2 \mathrm{e}) ; \mathrm{C}_{\mathrm{hs}}$ is the carbon emission from waste transportation. ccc can be calculated by referring to equation (6), and $\mathrm{C}_{\mathrm{fys}}$ can be calculated by referring to equation (4). $\mathrm{C}_{\mathrm{hs}}$ is the carbon reduction from waste recycling, which is estimated by referring to relevant scholars' studies.

\section{Case calculation analysis}

\subsection{Case Building Overview}

The case building is located in a community in Xi'an, Shaanxi Province. This study takes one of the buildings, $32 \#$, as an example to account for the carbon emissions of this residential building. $32 \#$ has a design life of 50 years; 
the building height is $96.00 \mathrm{~m} ; 33$ floors above ground and 2 floors below ground; reinforced concrete shear wall structure, seismic intensity 8 degrees; there are 1 unit with four households per floor, and the construction area is 13675.94 square meters.

\subsection{Whole Life Carbon Calculation}

\subsubsection{Calculation of carbon emissions in the planning and design phase}

The carbon emission in the planning and design phase is mainly the carbon emission generated by the energy used in the office equipment in that phase. According to equation (1), it is necessary to know the average daily electricity consumption of office equipment and the total office time of planning and design units. Due to the lack of data, this study assumes that the length of the planning and design is one month, and the office power consumption is based on GB50034-2013 of Architectural Lighting Design Standard and DBJ/T 61-60-2011 of Xi'an Energy Conservation Design Standard for Public Buildings, taking the lighting power density of the office area as $11 \mathrm{~W} / \mathrm{m} 2$, the air conditioning power consumption as $10 \mathrm{kWh}$ per day, the office area as $20 \mathrm{~m} 2$, and the office time as The final estimate of carbon emission in the planning and design stage is $370 \mathrm{kgCO} 2 \mathrm{e}$.

\subsubsection{Calculation of carbon emissions during the building material preparation phase}

(1) Production stage of building materials

In this paper, we screened out the main building materials from many building materials of 32\# residential building, counted their consumption and calculated the corresponding carbon emission, in the process of statistics, we categorized different materials, and divided the main building materials into steel (iron), commercial concrete, cement, lime, sand and gravel, wood, masonry materials, building ceramics, doors and windows, insulation materials, architectural coatings, waterproof materials and plastic building materials, totaling thirteen categories. The carbon emission calculation results of building materials of $32 \#$ residential building after categorization are shown in Table 4.

Table 4 Carbon emissions and percentage of major building materials

\begin{tabular}{ccc}
\hline Material Name & $\begin{array}{c}\text { Carbon emissions } \\
(\mathrm{kgCO} 2 \mathrm{e})\end{array}$ & Percentage (\%) \\
\hline $\begin{array}{c}\text { Steel } \\
\text { Commercial } \\
\text { concrete }\end{array}$ & 2137065.6 & $34.26 \%$ \\
Cement & 2530684.69 & $40.57 \%$ \\
Lime & 428959.16 & $6.88 \%$ \\
Sand and gravel & 72399.24 & $1.16 \%$ \\
Wood & 3581.82 & $0.06 \%$ \\
$\begin{array}{c}\text { Masonry } \\
\text { materials }\end{array}$ & 154132.9 & $2.47 \%$ \\
\hline
\end{tabular}

\begin{tabular}{|c|c|c|}
\hline $\begin{array}{l}\text { Building } \\
\text { ceramics }\end{array}$ & 32090.76 & $0.51 \%$ \\
\hline $\begin{array}{l}\text { Doors and } \\
\text { windows }\end{array}$ & 282542 & $4.53 \%$ \\
\hline $\begin{array}{l}\text { Insulation } \\
\text { materials }\end{array}$ & 316360.52 & $5.07 \%$ \\
\hline $\begin{array}{l}\text { Architectural } \\
\text { coatings }\end{array}$ & 146428.46 & $2.35 \%$ \\
\hline $\begin{array}{l}\text { Waterproof } \\
\text { materials }\end{array}$ & 15379.49 & $0.25 \%$ \\
\hline $\begin{array}{l}\text { Plastic building } \\
\text { materials }\end{array}$ & 17905.82 & $0.29 \%$ \\
\hline \multicolumn{3}{|c|}{ Total Carbon Emissions (kgCO2e): 6237574.8} \\
\hline
\end{tabular}

(2) Carbon emission in transportation of building materials

The transportation distance of the main building materials is shown in Table 5, and the above data are all from the final account of the project, and the transportation method is diesel transportation by road. According to formula (4), we can calculate the carbon emission in the transportation stage of $32 \#$ residential building.

Table 5 Carbon Emissions in Transportation Phase

\begin{tabular}{|c|c|c|c|}
\hline $\begin{array}{l}\text { Material } \\
\text { Name }\end{array}$ & $\begin{array}{l}\text { Material } \\
\text { volume }\end{array}$ & $\begin{array}{l}\text { Transportation } \\
\text { distance }(\mathrm{km})\end{array}$ & $\begin{array}{c}\text { Carbon } \\
\text { emission } \\
(\mathrm{kgCO} 2 \mathrm{e}) \\
\end{array}$ \\
\hline Steel & 872.602 & 240 & 41047.20 \\
\hline $\begin{array}{l}\text { Commercial } \\
\text { concrete }\end{array}$ & 44.036 & 40 & 345.24 \\
\hline Cement & 44.041 & 45 & 388.44 \\
\hline Lime & 287 & 45 & 9776.66 \\
\hline $\begin{array}{l}\text { Sand and } \\
\text { gravel }\end{array}$ & 8511.261 & 20 & 80073.94 \\
\hline Wood & 3314.47 & 60 & 156.17 \\
\hline $\begin{array}{l}\text { Masonry } \\
\text { materials }\end{array}$ & 96.915 & 50 & 949.77 \\
\hline $\begin{array}{l}\text { Building } \\
\text { ceramics }\end{array}$ & 563.82 & 30 & 3315.26 \\
\hline $\begin{array}{l}\text { Doors and } \\
\text { windows }\end{array}$ & 1020.6 & 40 & 13238.62 \\
\hline $\begin{array}{l}\text { Insulation } \\
\text { materials }\end{array}$ & 2806.01 & 100 & 1794.64 \\
\hline $\begin{array}{l}\text { Architectural } \\
\text { coatings }\end{array}$ & 1645.68 & 30 & 277.51 \\
\hline $\begin{array}{l}\text { Waterproof } \\
\text { materials }\end{array}$ & 30.299 & 20 & 118.77 \\
\hline $\begin{array}{c}\text { Plastic } \\
\text { building } \\
\text { materials }\end{array}$ & 595.13 & 30 & 118.29 \\
\hline
\end{tabular}

\subsubsection{Calculation of carbon emissions during the construction phase}

For the calculation of carbon emission in the construction stage, the number of construction machinery shifts in the bill of quantities of the case is counted, and the carbon emission caused by the use of construction machinery is calculated according to Table 3 , and then the carbon emission in this stage is estimated according to the provisions of the Carbon Emission Calculation Standard for Construction on the calculation of carbon emission of temporary facilities, i.e. $5 \%$ of the energy consumption of 
construction machinery. The calculation results are shown in Table6.

Table 6 Carbon emissions during the construction phase

\begin{tabular}{cc}
\hline Sub-phase & Carbon emission $(\mathrm{kgCO} 2 \mathrm{e})$ \\
\hline Construction Machinery & 124437.31 \\
Temporary facilities & 6221.87 \\
\hline
\end{tabular}

Total Carbon Emissions (kgCO2e): 130659.18

\subsubsection{Calculation of carbon emissions during the operation and maintenance phase}

(1) Carbon emissions from the operation phase of the building

Carbon emissions in the building operation phase include carbon emissions generated by energy consumption of air conditioning, heating, lighting and elevator during building operation. The energy consumption of building heating and air conditioning operation is calculated by using the building energy consumption simulation software DeST-h developed by Tsinghua University for building simulation. The energy consumption of lighting is estimated according to the relevant provisions in the Energy Conservation Design Standards for Residential Buildings in Xi'an (Draft for Public Comments). Elevator energy consumption was estimated according to the prediction model of elevator energy consumption provided in the Technical Conditions for Elevators. The carbon emission calculation results for this phase are shown in Table 7.

Table 7 Carbon Emissions in Building Operation Phase

\begin{tabular}{cc}
\hline Projects & $\begin{array}{c}\text { Annual Carbon Emissions } \\
(\mathrm{kgCO} 2 \mathrm{e} / \mathrm{a})\end{array}$ \\
\hline Heating & 200254.91 \\
Air Conditioning & 58763.61 \\
Lighting & 48077.46 \\
Elevator & 18205.95 \\
\hline
\end{tabular}

Total annual carbon emissions ( $\mathrm{kgCO} 2 \mathrm{e} / \mathrm{a}): 325301.93$

(2) Building maintenance stage

The carbon emission factors generated from the production and installation of building maintenance components in this stage refer to the research results of YJ Cang. The total quantity of the building materials being maintained and replaced was compiled from the project settlement according to equation (10) to obtain the carbon emission of $533942.47 \mathrm{kgCO} 2 \mathrm{e}$ in this stage.

\subsubsection{Calculation of carbon emissions during the dismantling and disposal phase}

(1) Carbon emission in the demolition stage

Carbon emission in the demolition stage is mainly the energy consumption of demolition machinery and equipment and transportation equipment, which is the reverse process of building construction. Most demolition projects use manual demolition and mechanical demolition. This study adopts the method recommended in the Standard for Calculating Carbon Emissions of Buildings GB51366-2019 to calculate the energy consumption and carbon emissions in this stage.

Firstly, based on the list of component quantities in the project settlement of $32 \#$ building, the component quantities of the demolition stage of 32\# building were sorted out according to the chapter of "demolition project" in the national quota of "housing construction and decoration project consumption quota".

Then, according to the amount of labor, materials and machinery used in each unit of the demolition work, the amount of labor, materials and machinery required for the demolition work of $32 \#$ building was calculated.

Finally, the total carbon emission in the demolition stage of 32\# building was calculated according to the corresponding carbon emission factors. The results are shown in Table 8.

Table 8 Summary of carbon emissions during the demolition phase

\begin{tabular}{|c|c|c|c|c|}
\hline Stage & $\begin{array}{l}\text { Name of work } \\
\text { machine }\end{array}$ & Unit & Quantity & $\begin{array}{l}\text { Carbon } \\
\text { emission } \\
(\mathrm{kgCO} 2 \mathrm{e})\end{array}$ \\
\hline \multirow[b]{3}{*}{$\begin{array}{l}\text { Building } \\
\text { demolition }\end{array}$} & Electricity & $\mathrm{kWh}$ & 28344.23 & 18908.44 \\
\hline & $\begin{array}{l}\text { Truck-mounted } \\
\text { crane } 8 \mathrm{t}\end{array}$ & shifts & 0.034 & 4.31 \\
\hline & $\begin{array}{c}\text { Single cage } \\
\text { construction } \\
\text { elevator } 1 \mathrm{t} \\
75 \mathrm{~m}\end{array}$ & shifts & 536.94 & 15158.71 \\
\hline \multicolumn{3}{|c|}{ Total Carbon Emissions ( $\mathrm{kgCO} 2 \mathrm{e})$} & \multicolumn{2}{|c|}{34071.46} \\
\hline $\begin{array}{l}\text { Waste } \\
\text { outbound } \\
\text { transportation }\end{array}$ & Dump truck $8 \mathrm{t}$ & shifts & 1012.58 & 128313.41 \\
\hline \multicolumn{3}{|c|}{ Total Carbon Emissions (kgCO2e) } & \multicolumn{2}{|c|}{128313.41} \\
\hline
\end{tabular}

(2) Carbon emission from waste recycling

The carbon reduction from waste recycling is shown in Table 9 below.

Table 9 Waste Recovery Carbon Reduction

\begin{tabular}{|c|c|c|c|}
\hline $\begin{array}{l}\text { Construction } \\
\text { waste types }\end{array}$ & $\begin{array}{c}\text { Recycling } \\
\text { rate }(\%)\end{array}$ & $\begin{array}{l}\text { Recycling } \\
\text { volume }\end{array}$ & $\begin{array}{l}\text { Carbon } \\
\text { emission } \\
\text { reduction } \\
(\mathrm{kgCO} 2 \mathrm{e})\end{array}$ \\
\hline Concrete & 70 & $7658.53 \mathrm{t}$ & 49244.35 \\
\hline $\begin{array}{l}\text { Bricks and } \\
\text { blocks }\end{array}$ & 70 & $\begin{array}{c}135.1 \\
\text { Thousands of } \\
\text { pieces }\end{array}$ & 47149.9 \\
\hline Steel & 90 & $760.35 t$ & 1755572.12 \\
\hline $\begin{array}{l}\text { Windows and } \\
\text { doors }\end{array}$ & 80 & $1836.79 \mathrm{~m}^{2}$ & 85043.38 \\
\hline Wood & 65 & $114.11 \mathrm{~m}^{3}$ & 15861.29 \\
\hline Plastic pipe & 25 & $0.46 \mathrm{t}$ & 4480.4 \\
\hline \multicolumn{4}{|c|}{$\begin{array}{c}\text { Total carbon emission reduction }(\mathrm{kgCO} 2 \mathrm{e}) \\
1957351.44\end{array}$} \\
\hline
\end{tabular}

\subsubsection{Total Building Life Cycle Carbon Emissions}

According to the above calculation results, the total life-cycle carbon emission of $32 \#$ residential building can be obtained as $21526227.40 \mathrm{kgCO} 2 \mathrm{e}$. The carbon 
emission per unit building area is $1574.02 \mathrm{kgCO} 2 \mathrm{e} / \mathrm{m} 2$, see Table 10.

Table 10 Whole life cycle carbon emissions of Building 32\#

\begin{tabular}{cc}
\hline Stages/Sub-Stages & Carbon emission $(\mathrm{kgCO} 2 \mathrm{e} / \mathrm{m} 2)$ \\
\hline Building material preparation & 467.18 \\
stage & 9.55 \\
Construction Build Phase & 1228.53 \\
Operation and maintenance \\
phase
\end{tabular}

Total life-cycle carbon emissions $(\mathrm{kgCO} 2 \mathrm{e}): 1574.02$

\section{Results and discussion}

\subsection{Whole Life Cycle Carbon Emission Analysis}

Based on the results of the previous calculations, the carbon emissions of each stage of the building and their proportion are summarized in Figure 1 and Figure 2.

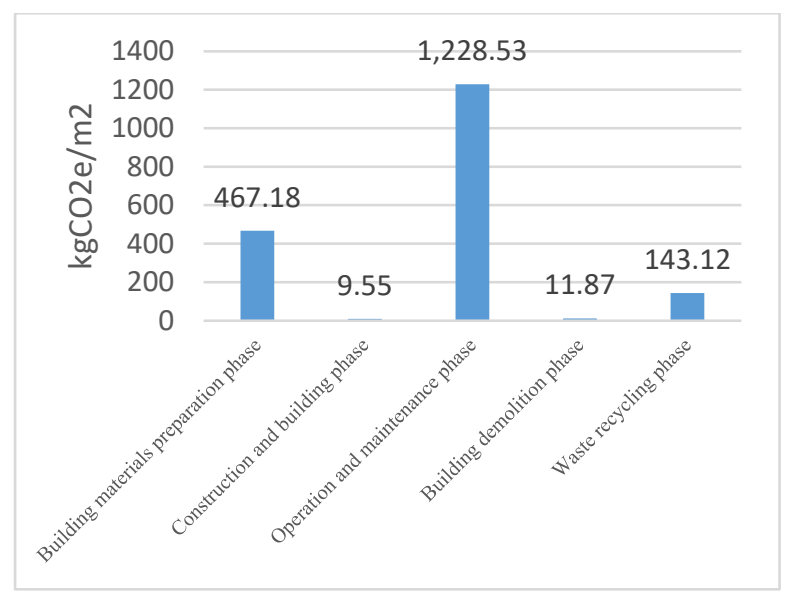

Figure 1 Carbon emissions in the main stages of the life cycle of Building 32\#

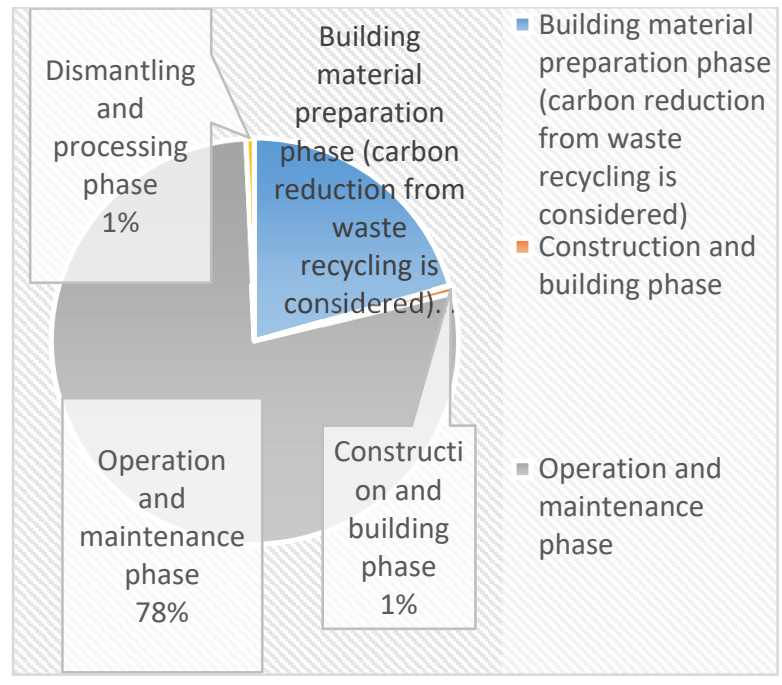

Figure 2 Carbon emission share of 32\# main life cycle stages
The above graph shows that the carbon emission of the $32 \#$ residential building is $467.18 \mathrm{kgCO} 2 \mathrm{e} / \mathrm{m} 2$ in the building material preparation stage, $1228.53 \mathrm{kgCO} 2 \mathrm{e} / \mathrm{m} 2$ in the operation and maintenance stage, and 9.55 $\mathrm{kgCO} 2 \mathrm{e} / \mathrm{m} 2$ in the construction and building stage.

The proportion of carbon emissions from the operation and maintenance phase of the $32 \#$ residential building is the largest, reaching $78.05 \%$, followed by the building materials preparation phase, which accounts for $20.59 \%$ of carbon emissions, and the proportion of carbon emission reduction from the demolition and disposal phase is $0.77 \%$. It can be seen that the building operation and maintenance stage and the building materials production stage are the key stages of building emission reduction and should be studied with emphasis. The carbon emissions from the construction and demolition stages account for very little of the total carbon emissions in the building life cycle, so this paper does not focus on them.

\subsection{Analysis of carbon emissions in the production phase of building materials}

As can be seen from Table 4, among the main building materials used in Building 32\#, the sum of carbon emissions from steel and commercial concrete exceeds $70 \%$ of the total carbon emissions from the production of building materials and occupies an important position in the carbon emissions from building materials. The sum of carbon emissions from the five categories of building materials: commercial concrete, steel, cement, windows and doors, and insulation materials accounts for more than $90 \%$ of the production phase of building materials; thus, focusing on the carbon emissions from the five categories of building materials: commercial concrete, steel, cement, windows and doors, and insulation materials can effectively assess the degree of environmental impact of construction carbon emissions.

The carbon reduction from recyclable construction waste can offset part of the carbon emissions from the production of building materials, and it is suggested that the environmental impact of carbon emissions at this stage can be reduced by increasing the recycling rate of existing building materials or adopting green building materials.

\subsection{Analysis of carbon emissions in building operation Stages}

According to the calculation results, the annual carbon emissions per unit floor area of heating, air conditioning, lighting and elevator in the operation phase of 32\# residential building and their percentages are shown in Figure 3 and Figure 4. 


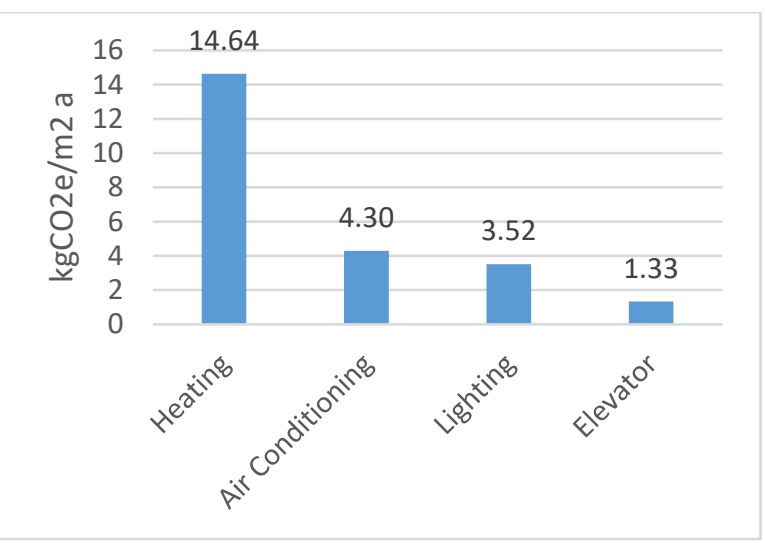

Figure 3 Carbon emissions from heating and air conditioning systems in the residential operation phase

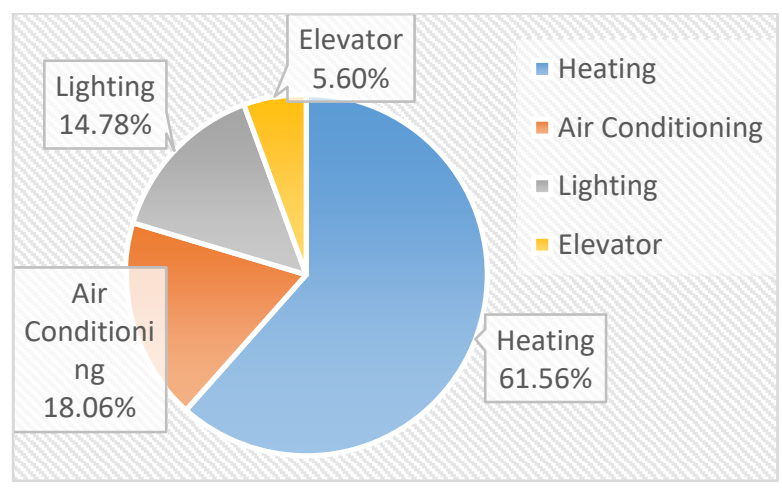

Figure 4 Carbon emission share of residential heating and air conditioning systems

It can be seen from the figure that the largest proportion of carbon emissions during the building operation phase is the carbon emissions caused by heating energy consumption, accounting for $61.56 \%$. The carbon emissions caused by the energy consumption of air-conditioning accounted for $18.06 \%$, and the carbon emissions caused by the energy consumption of building lighting accounted for $14.78 \%$. The carbon emissions caused by elevator energy consumption accounted for $5.60 \%$. Emission reduction focuses on how to reduce the energy consumption of building air conditioning and heating.

\section{Conclusions}

Based on the whole life cycle assessment method, this paper divides the building life cycle into five stages: planning and design, building materials preparation, operation and maintenance, construction and demolition processing. the calculation boundary, calculation unit and carbon emission factor were determined. According to the carbon emission coefficient method, a more comprehensive and operational carbon emission calculation formula has been established with reference to the existing research results of domestic and foreign scholars.

This paper takes a high-rise residential building in $\mathrm{Xi}$ 'an as an example, the carbon emissions at each stage of the life cycle was calculated by taking a high-rise residential building in Xi'an as an example. It can provide a reference for the calculation of carbon emissions throughout the life cycle of other buildings. Through the analysis of the calculation results, the essential points of carbon emission reduction at each stage of the building's life cycle are proposed. Therefore, it is hoped that it can guide buildings to consider energy conservation and carbon reduction throughout their life cycle during their design stage, enhance the energy conservation awareness of building users. Moreover, data references for future building carbon emission reduction efforts are provided also at the same time.

\section{References}

1. Song JZ, Guo XY, Wang XP, Hu Z. (2019) Analysis of regional differences and convergence of carbon emission efficiency in China's construction industry--based on SBM model and panel unit root test $[\mathrm{J}]$. Journal of Xi'an University of Architecture and Technology (Natural Science Edition), 51(02):301-308.

2. Cole R J. (1999) Building environmental assessment methods: clarifying intentions[J].Building Research \& Information. 27(4):230-246.

3. Jaehun S, Jehean S, Changbae P. (2016) The air emission assessment of a South Korean apartment building's life cycle, along with environmental impact[J]. Building and Environment, 95.

4. Leif G,Anna 3oelsson,Roger S. (2010) Life cycle primary energy use and carbon emission of an eight-storey wood-framed apartment building [J].Energy and Buildings, 42(2):230-242.

5. Liu N, Wang J, Li R.(2009)Calculation of CO_2 emissions from urban settlements in China[J]. Journal of Tsinghua University (Natural Science Edition), 49(09):1433-1436.

6. Zhang W., Wu X., Xiao Houzhong. An empirical study on the environmental impact of residential buildings in Beijing $[\mathrm{J}]$. Environmental Protection, 2004(09):40-43.

7. Luo Z. Research on the calculation method and emission reduction strategy of building life cycle carbon dioxide emission[D]. Xi'an:Xi'an University of Architecture and Technology,2016. 